\title{
Difference of Consumer Attitude based on Level of Product Information and Service Quality
}

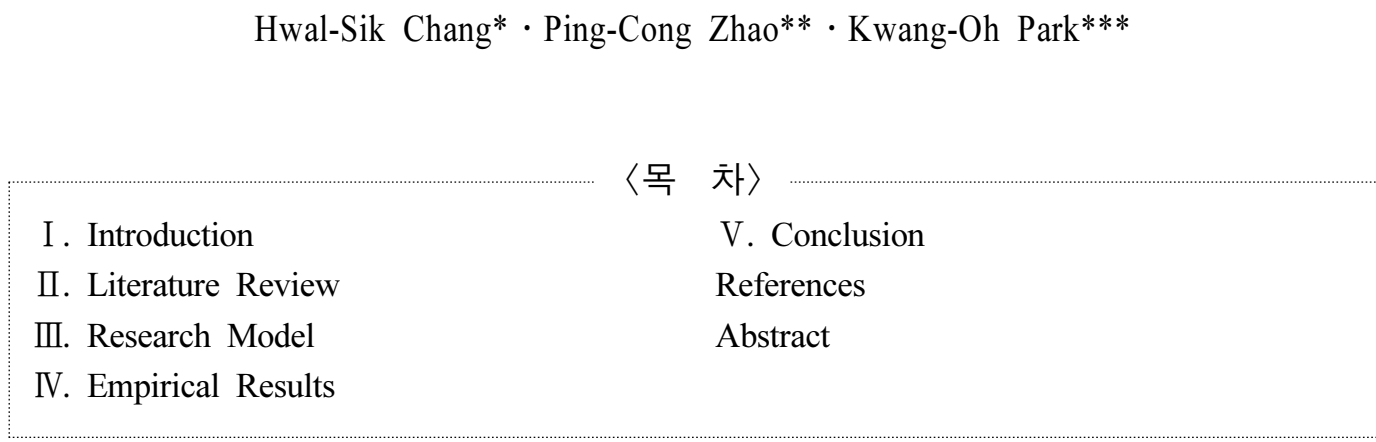

\section{Introduction}

The number of internet users has been growing in exponential speed since the beginning of this century. During the past few years, there have seen an explosion of attention to the role played by information and communications technology in shaping the global economics.

With the rapid development in electronic commerce, business companies are taking advantage of E-commerce to sell products, provide services, interact with customers, and so on, in order to make themselves more competitive in today's international market.

However, previous studies focus on both mutual relation and on preceding relations of TAM factors(e.g. perceived usefulness, perceived ease of use, attitude towards, behavioural intention to use, actual system use).

Accordingly, it is necessary to use extended TAM. Level of product information and level of product service are added in this study, both of which are important factors influencing consumer attitude, but have not been fully studied.

The purpose of this paper is to find out the difference between consumer attitude based on

* 부산대학교 상과대학 경영학부 교수 (제1저자), hwschang@pusan.ac.kr 부산대학교 상과대학 경영학부 박사과정 (공동저자), zpcon@pusan.ac.kr *** 부산대학교 상과대학 경영학부 강사 (교신저자), kopark@pusan.ac.kr 
level of product information and service quality. Then we aim to find out the effect of product information and service quality on perceived value, perceived risk, purchase intention and word of mouth. In this study, we designed four kinds of web pages which show different levels of product information and service quality. We gave four kinds of web pages together to each respondent and asked him to finish the questionnaire after looking through these web pages. Also, if we distribute the questionnaires in the same order, the learning effect has arisen. For removing the learning effect, we distribute the questionnaires in special order.

\section{Literature Review}

\subsection{Product Information}

The World Wide Web has great effect on online shopping, however, it faces distinct limitations, since shopping for products is more difficult when the product is not physically available(Nancy, 2002). In addition, information content has consistently shown to affect user satisfaction in online shopping(Lightner, 2001; Wang et al., 2001). Content quality is considered high when site content corresponds well to consumers' informational needs and their ability to consume the information(Davern et al., 2000). The effect of product information to perceived value has been studied by Hartnett(1998). When choosing a product, consumers will consider the attribute of product information such as the price of a product, pictures, videos of a product, and so on.

Reliability represents the ability of the internet shopping web sites to describe product information correctly, fulfill orders correctly, deliver products promptly, and keep personal information secure(Janda et al., 2002; Kim \& Lee, 2002). Customers expect internet shops to respond to their inquires promptly (Liao \& Cheung, 2002). Robert(2008) have evaluated sufficiency of product cost for product mix and pricing decisions under alternative types of demand information. Perceived Utility of web sites is positively associated with customer trust in internet shops (Koufaris \& Hampton, 2004). Therefore, increased utility of internet shops can result in increased perceived value of products, and decreased perceived risk of internet shops. And it has been known that for consumer attitude definiteness of product information is critical(Nancy, 2002).

\subsection{Service Quality}

Service quality is defined as features of web page services on product quality which satisfy customers' demands. Extensive studies have found reliability to be important in determining service quality (Lee, 2005; Zeithaml \& Bitner, 2000). In the study about service quality, there are five factors that reliability, assurance, 
tangibles, empathy, and responsiveness. Of the five service quality dimensions, reliability has generally surfaced as the most critical dimension, based on both direct measures of relative importance and importance weights derived from regression analyses(Zeithaml, 2002). And the reliability means if the seller can commitment to consumer all the time. Responsiveness means that the seller response the consumer's need as soon as quickly and render services quickly. Responsiveness is that willingness to help customers and provide prompt service. Assurance means knowledge and courtesy of employees and their ability to inspire trust and confidence. Empathy is that caring, individualized attention the firm provides its customers. Tangibles means that appearance of physical facilities, equipment, personnel, and communication materials (Parasuraman , 1997).

\subsection{Perceived Value}

In previous literatures, the perceived value of consumers affects purchase intention directly(Eggert \& Ulaga, 2002; Petrick, 2002). Perceived value of customer is the total evaluation of a product or service after the customer has weighed the perceived benefit and the cost to obtain the product or service. Customers' perceived value is the subjective perception of the products or service, which is different from the objective value of products or service.

The core of customers' perceived value involves weighing perceived benefits and perceived sacrifices. This concept includes two kinds of meanings: first, value is personalized and should be different based on different people, for example, different customers show different perceived value to the same products or service. Second, value represents a balance between benefit and cost, because customers decide to buy by their own perception rather than only by one certain factor.

Thus, customer value regulates "behavioral intentions of loyalty toward the service provider as long as such relational exchanges provide superior value" (Sirdeshmukh et al., 2002).

\subsection{Perceived Risk}

Perceived risk is defined as consumers' subjective belief of suffering a loss in pursuit of a desired outcome(Pavlou, 2003; Son \& Lee, 2003). Consumers attempt to reduce their anxiety by collecting more information and by seeking the recommendations of a peer group or an entity considered an expert on the subject matter. A study(Julian et al., 1999) extends previous research on perceived value by including the role of perceived risk within a model of the antecedents and consequences of perceived value.

The mediating impact of perceived risk on the quality-value relationship was specifically 
examined. Empirical results confirmed that not only do perceived product and service quality lead to perceived value for money in a service encounter but that these quality components reduce perceived risk.

Perceived risk was found to play an important role in the perceived product and service quality-value for money relationship and was found to be a significant mediator of this relationship.

\subsection{Purchase Intention}

There are two types of purchase intention: repurchasing intentions and shopping intention. Repurchasing intention reflects whether we anticipate buying the same product or brand again. Shopping intention indicates where we plan on making our product purchases. Both internal and external information search may increase consumers' intention to purchase or repurchase on the Internet, which generally leads to the purchase stage of decision making(Blackwell et al., 2001).

Because the Internet is perceived as a powerful tool for information search, marketers remain highly interested in understanding the relationship between consumers' use of the Internet for information search and their choice of channel for the final purchase. On the theoretical side, due to the potential importance of search in internet behavior, academicians such as Klein(1998) argue that search processes be made part of interactive consumer models as critical predictors of Internet consumer behavior.

Purchase intention is that consumers who self perform services that are readily available for purchase often do so to conserve effort(Kimery $\&$ McCord, 2002). There is a positive correlation between commercial enterprise web sites' privacy and security policies and consumers' online purchase intentions(Miyazaki \& Fernandez, 2001). Customer service policies that are generic or limited in content may not be useful in building consumers' perception of web vendor quality(Liao \& Cheung, 2001). Further research to investigate the components of service recovery and their interactive effects on repurchase intentions will be possible(Grewal \& Levy, 2007).

\subsection{Word of Mouth}

Word of mouth(WOM) is a consumer dominated channel of marketing communication where the sender is independent of the market(Chrysanthos, 2003). Information in traditional word of mouth communication is exchanged through private conversations, therefore, direct observation has been difficult. However, online conversations may offer an easy and cost-effective opportunity to measure word of mouth. Electronic word of mouth communication through electronic media allows consumers to not only obtain information related 
to goods and services from the few people they know, but also form a vast, geographically dispersed group of people, who have experience with relevant products or services(Ratchford et al., 2003; Yoon et al., 2008).

Throughout the electronic word of mouth activities, consumers can obtain high levels of market transparency. In addition, they can take on a more active role in the value chain and influence products and prices according to individual preferences. Because of such importance and popularity of electronic word of mouth communication, studies in the last few years were actively examining factors which influence the effect of electronic word of mouth on consumer behavior.

\section{Research Model}

The purpose of this paper is to find out the difference of consumer attitude based on level of product information and service quality. Then we want to find out the effect of product information and service quality on perceived value, perceived risk, purchase intention and word of mouth.

In our study, we designed four kinds of web pages which show different levels of product information and service quality. The first web page has adequate product information and adequate service information. The second web page has the same product information but much less service information than the first one. The third web page has the same service information as first web page but has much less product information than the first one. And the last web page has both inadequate product information and service information. We include six factors in this study, which are level of product information, level of service quality, perceived value, perceived risk, purchase intention, and word of mouth.

During our survey, we gave four kinds of web pages together to each respondent and asked him to finish the questionnaire after looking through these four kinds of different web pages, because different respondents can give different survey results. Also, if we distribute the questionnaires in the same order, the learning effect has arisen. For disappearing learning effect, we distribute the questionnaires in the different order. And all variables are measured using likert 5 point scale, while perceived risk is analyzed after using reverse scale.

Step 1. We have 24 kinds of situations

$<4$ Factorial $=24(4 * 3 * 2 * 1)>$

Step 2. Accordingly, we distributed our questionnaire in different order. Of Course the number of samples is 48,2 respondents answered the questionnaire in the same order.

Step 3. Therefore, 48 respondents finished the questionnaire after reading the four kinds of questionnaire, and 192 copies of questionnaire were collected in total.

Moreover, in this study, we test the sample by 
the following process in order to test whether the respondent or the order in which the four kinds of questionnaire are distributed has effect on the survey results.

Mathematically, the research model can be summarized as

$$
y=a X_{1}+b X_{2}+c X_{3}+d
$$

where $\mathrm{Y}$ is the value of response; $\mathrm{a}, \mathrm{b}$, and $\mathrm{c}$ are coefficients of $\mathrm{X} 1, \mathrm{X} 2$ and $\mathrm{X} 3$, respectively, and $\mathrm{d}$ is a constant; $\mathrm{X} 1$ is the respondent; $\mathrm{X} 2$ is the sequence of response; $\mathrm{X} 3$ is the difference level of product information and service quality web page.

In Table 1, as for level of product information, the value of $R$ square is 0.54 and the $p$-value of this model is 0.00 . When the coefficient of $\mathrm{X} 1$ is 0.01 and the $\mathrm{t}$-value of $\mathrm{X} 1$ is $1.52, \mathrm{X} 1$ does not affect the result, which means the respondent does not affect the result of level of product information. When the coefficient of X2 is -0.04 and the $\mathrm{t}$-value of $\mathrm{X} 2$ is $0.74, \mathrm{X} 2$ does no affect the result of level of product information, which means the sequence of response does not affect the result of level of product information. When the coefficient of $\mathrm{X} 3$ is 0.57 and the t-value of $\mathrm{X} 3$ is 4.20 , the difference of level of product information affects the result. Therefore, only $\mathrm{X} 3$ affects the result of level of product information.

As for perceived service quality, the value of $\mathrm{R}$ square is 0.34 and the $\mathrm{p}$-value of this model is 0.00 . When the coefficient of $\mathrm{X} 1$ is 0.00 and the $\mathrm{t}$-value of $\mathrm{X} 1$ is $0.17, \mathrm{X} 1$ does not affect the result, which means the respondent does not affect the result of perceived service quality. When the coefficient of X2 is 0.09 and the t-value of $\mathrm{X} 2$ is $1.43, \mathrm{X} 2$ does not affect the result of perceived service quality, which means the sequence of response does not affect the result of level of product information. And when the coefficient of X3 is 0.49 and the t-value of $\mathrm{X} 3$ is 3.44 , different perceived service quality affects the result. Therefore, only X3 affects the result of perceived service quality.

Then, we use t-test to analyze whether the

$<$ Table $1>$ Verification of Sample

\begin{tabular}{|c|c|c|c|c|c|}
\hline & R Square & $\begin{array}{l}\text { p-value } \\
\text { (Model) }\end{array}$ & $\begin{array}{c}\mathrm{X}_{1} \\
\text { (t-value) }\end{array}$ & $\begin{array}{c}\mathrm{x}_{2} \\
\text { (t-value) }\end{array}$ & $\begin{array}{c}\mathrm{X}_{3} \\
\text { (t-value) }\end{array}$ \\
\hline $\begin{array}{c}\text { Level of } \\
\text { Product } \\
\text { Information }\end{array}$ & 0.54 & 0.00 & $\begin{array}{c}0.01 \\
(1.52)\end{array}$ & $\begin{array}{l}-0.04 \\
(0.74)\end{array}$ & $\begin{array}{l}0.57^{* * *} \\
(4.20)\end{array}$ \\
\hline $\begin{array}{l}\text { Level of } \\
\text { Service } \\
\text { Quality }\end{array}$ & 0.34 & 0.00 & $\begin{array}{c}0.00 \\
(0.17)\end{array}$ & $\begin{array}{c}0.09 \\
(1.43)\end{array}$ & $\begin{array}{l}0.49^{* * *} \\
(3.44)\end{array}$ \\
\hline$* * \mathrm{p}<0.05$ & $p<0.001$ & ) $\mathrm{t}-\mathrm{va}$ & & & \\
\hline
\end{tabular}


respondents can feel different between level of product information and level of service quality. In table 2, good product information refers to the mean resulting from respondents who were surveyed by giving webpage with adequate product information, and bad product information refers to the mean resulting from respondents who were surveyed by giving webpage with inadequate product information. And good and bad service quality are in a similar manner.

In this table 2, the mean of good product information is 3.73 and the mean of bad product information is 2.08 . The $\mathrm{t}$-value and p-value of both product information are 14.80. and 0.00 respectively. The data show that the effect of different level of product information is different. And the mean of good service quality is 3.36 and the mean of bad service quality is 2.31. The $t$-value and $p$-value of both perceived service quality are 10.28 and 0.00 respectively, which means the effect of different service quality is different.

Then we want to find out the effect of product information and service quality on perceived value, perceived risk, purchase intention and word of mouth. The research model of this study illustrated in Figure 1. Based on the literature review above, the following hypothesis are proposed.

H1: The level of product information positively influences on perceived value.

The first hypothesis examines the relationship between level of product information and perceived value. From a retailing perspective, Hartnett(1988) noted that when retailers satisfy people-based needs, they are delivering value, which puts them in a much stronger position in the long term. That also says in order to remain competitive, the sellers of online shop would have to lower their prices(Dhruv et al., 2003). Therefore, adequate product information positively affects perceived value of web sites in $<$ Table 2> t-test

\begin{tabular}{c|c|c|c|c}
\hline \multirow{2}{*}{} & \multicolumn{2}{|c|}{ Level of Product Information } & \multicolumn{2}{c}{ Level of Service Quality } \\
\cline { 2 - 5 } & $\begin{array}{c}\text { Good Product } \\
\text { Information }\end{array}$ & $\begin{array}{c}\text { Bad Product } \\
\text { Information }\end{array}$ & $\begin{array}{c}\text { Good Service } \\
\text { Quality }\end{array}$ & $\begin{array}{c}\text { Bad Service } \\
\text { Quality }\end{array}$ \\
\hline Average & 3.73 & 2.08 & 3.36 & 2.31 \\
\hline t-value & \multicolumn{2}{|c}{14.80} & \multicolumn{2}{|c}{$0.00^{* * *}$} \\
\hline p-value & $0.00^{* * *}$ & \\
\hline$* * \mathrm{p}<0.05, * * * \mathrm{p}<0.001$ & \multicolumn{2}{|c}{} \\
\hline
\end{tabular}




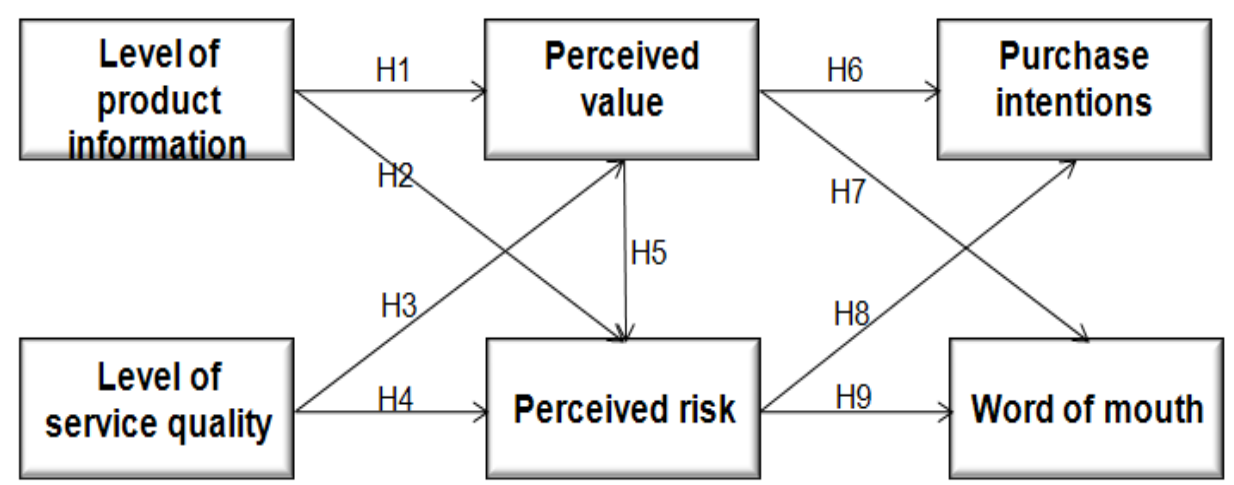

<Figure 1> Research Model

online shopping. The level of product information of web sites is positively associated with customer' perceived value in online shops(Koufaris \& Hampton, 2004). Therefore, the information of online shops can increase the perceived value of products.

$\mathrm{H} 2$ : The level of product information negatively influences on perceived risk.

The second hypothesis examines the relationship between level of product information and perceived risk. Park et al.(2005) concluded that people exposed to Web sites with products in motion and larger product images will perceive less risk. And the information of internet shops can decrease perceived risk of internet shops(Koufaris \& Hampton, 2004). Finally, size and movement interact to affect perceived risk. The reason is that a customer could easily make the decision to buy the products from the web site since the customer could return the product without any charge if he found the product was not good for him. Moreover, these factors will also help a customer believe in the online shop. Besides, the background information would help a customer know the online shop so it was also important for the perceived risk. Therefore, based on the above literature review, the following hypothesis is proposed.

H3: Level of service quality positively influences on perceived value.

The third hypothesis examines the relationship between perceived service quality and perceived value. In the study of Jillian et al.(1999), the author examined the way in which service quality at the point of purchase influences consumers' perceptions of value and willingness to buy. Service quality is the characteristics of products or services which fill product quality or customer's perceived value. Taylor \& Hunter(2002) related that the perceived service quality positively contributes to perceived value 
of customer. Zeithaml(2002) proposed that service quality is a sum total of customer's demand and latent demand, which is a degree of perceived value and satisfaction of customers.

H4: Level of service quality negatively influences on perceived risk.

The fourth hypothesis examines the relationship between perceived service quality and perceived risk. One of the service quality attributes is reliability, which refers to the accuracy of the service outcome and customer perceived risk(Zeithaml \& Biner, 2000). The level of perceived service quality can affect customer's purchase intention, and at the same time, it also shows the design level of a web site. If a web site has a high design level, there may not be a high maintenance level. And if the design level of web site is not good, there must be a low maintenance level (Blackwell et al., 2001). The convenience of purchase is affected by a variety of firm related factors, including the physical service environment, information provided consumers, company branding, and service system design(Leonard et al., 2002). Time risk refers to the time spent for the purchase of a product and the time wasted in the case of a bad purchase(Cunningham et al., 2005).

H5: Perceived value negatively influences on perceived risk.
The fifth hypothesis between perceived value and perceived risk examines the relationship between perceived risk and perceived value. Consumer purchase intention provides an acceptable proxy for actual online purchase behavior. Additionally, previous studies(Park, 2005; Ernst \& Young, 2001) have suggested that customer perception of service value positively influences purchase intention, and perception of risk negatively influences purchase intention. Therefore, based on the above literature review, the following hypothesis is proposed.

H6: Perceived value positively influences on purchase intention.

The sixth hypothesis examines the relationship between perceived value and purchase intention. High value perceptions can explain why customers stay with a service provider even in the presence of lower-cost alternatives. The service quality-purchase intention relationship can be explained by cognitive evaluations of the service which finally lead to a behavioral response from the customer. Perceived value is the essential result of marketing activities and is a first-order element in relationship marketing(Oh, 2003; Dumond, 2000). Marketing researchers have recently been trying to grapple with this concept and to study it in greater depth. The service quality - purchase intention relationship can be explained by cognitive evaluations of the service which finally lead to a behavioral response from 
the customer.

H7: Perceived value positively influences on word of mouth.

The Seventh hypothesis examines the relationship between perceived value and word of mouth. Word of mouth of customers is determined by the value of the product. Customer perceived value is a strategic imperative that firms must pay attention to, and has become a major focus of interest in marketing(Lin et al., 2005). Literature supports the general notion that pricing factors affect

$<$ Table 3> Operation Definition

\begin{tabular}{|c|c|c|}
\hline Factor & Item & Reference \\
\hline \multirow{4}{*}{$\begin{array}{l}\text { Level of } \\
\text { Product } \\
\text { Information }\end{array}$} & Reliability of Product Information & \multirow{4}{*}{ Nancy (2002) } \\
\hline & Sufficiency of Product Information & \\
\hline & Utility of Product Information & \\
\hline & Definiteness of Product Information & \\
\hline \multirow{4}{*}{$\begin{array}{c}\text { Level of } \\
\text { service } \\
\text { Quality }\end{array}$} & Reliability of Service & \multirow{4}{*}{$\begin{array}{l}\text { Harold \& Linda } \\
\qquad(2004)\end{array}$} \\
\hline & Convenience of Purchase & \\
\hline & Convenience of Payment & \\
\hline & Convenience of Returned & \\
\hline \multirow{4}{*}{$\begin{array}{l}\text { Perceived } \\
\text { Value }\end{array}$} & Economical Value & \multirow{4}{*}{ Francois et al.(2009) } \\
\hline & Satisfying Value & \\
\hline & Pleasurement of Purchasing & \\
\hline & Product Value & \\
\hline \multirow{4}{*}{$\begin{array}{l}\text { Perceived } \\
\text { Risk }\end{array}$} & Perceived Financial Risk & \multirow{4}{*}{$\begin{array}{l}\text { Jillian \& Soutar } \\
\text { (2001) }\end{array}$} \\
\hline & Perceived Risk of Time & \\
\hline & Perceived Negative Risk & \\
\hline & Perceived Personal Risk & \\
\hline \multirow{4}{*}{$\begin{array}{l}\text { Purchase } \\
\text { Intention }\end{array}$} & Positive Purchase Intention & \multirow{4}{*}{$\begin{array}{l}\text { Kimery } \& \text { McCord } \\
\qquad(2002)\end{array}$} \\
\hline & Continuous Revisit Intention & \\
\hline & Continuous Repurchase Intention & \\
\hline & Intention to Spend Time for Purchasing Another Product & \\
\hline \multirow{3}{*}{$\begin{array}{l}\text { Word of } \\
\text { Mouth }\end{array}$} & Other Users' Experience & \multirow{3}{*}{$\begin{array}{l}\text { Banerjee \& Fudenberg } \\
\qquad(2004)\end{array}$} \\
\hline & User's self Experience & \\
\hline & Word of Mouth of All Users & \\
\hline
\end{tabular}


perceived value, which, in turn, contributes to customer loyalty (Reichheld, 1996). And word of mouth networks constitute an ancient solution to a timeless problem of social organization: the elicitation of good conduct in communities of self-interested individuals who have short-term incentives to cheat one another(Chrysanthos, 2003). Word of mouth is a comparison between the perceived value and the perceived post-purchase value(Parasuraman, 1997).

H8: Perceived risk negatively influences on with purchase intention.

The eighth hypothesis examines the relationship between perceived risk and purchase intention. Vijayasarathy \& Jones(2000) found that consumers' perceived risk is an important factor that influences intention to shop online. Shoppers' confidence in judging quality of products or in making decisions to purchase products may reduce perceived risk, as consumers develop shopping experience from the Internet(Yoh et al., 2003). Therefore, based on the above literature review, the following hypothesis is proposed.

H9: Perceived risk negatively influences on word of mouth.

The ninth hypothesis examines the relationship between perceived risk and word of mouth. Word of mouth of products may serve as additional product information(Chrysanthos,
2003). For example, people can talk about a product by telling the experiences of using it to their friends and families, but not make them perceive the product enough. This may increase perceived risk, which is defined as the nature and amount of uncertainty perceived by consumers in contemplating a particular purchase decision and make shoppers avoid purchasing product from the Internet(Ernst \& Young, 2001). And Shopper's perceived risk negatively affects word of mouth(Yoh et al., 2003). Word of mouth networks are artificially induced through explicitly designed information systems(Chrysanthos, 2003). So, it is negatively associated with the effect of word of mouth to perceived risk.

\section{IV . Empirical Results}

This research is analyzed through two aspects. First, according to level of product information and level of product service, there is difference in perceived value, perceived risk, purchasing intention, and word of mouth. Therefore, we analyze the web pages through ANOVA. In this table 4, we get the p-value of the six constructs. The p-value of level of product information is 0.000 , the $\mathrm{p}$-value of level of service quality is 0.000 , the p-value of perceived value is 0.000 , the p-value of perceived risk is 0.000 , and the p-value of purchase intentions is 0.000 , and word of mouth 
$<$ Table 4> ANOVA test

\begin{tabular}{|c|c|c|c|}
\hline \multirow{2}{*}{ Construct } & F statistic ( F crit) & \multirow{2}{*}{ Construct } & F statistic ( $F$ crit) \\
\hline & $\mathrm{p}$-value & & $p$-value \\
\hline \multirow{2}{*}{$\begin{array}{l}\text { Level of Product } \\
\text { Information }\end{array}$} & $75.682(2.653)$ & \multirow{2}{*}{ Perceived Risk } & $22.154(2.653)$ \\
\hline & 0.000 & & 0.000 \\
\hline \multirow{2}{*}{$\begin{array}{c}\text { Level of Service } \\
\text { Quality }\end{array}$} & $31.655(2.653)$ & \multirow{2}{*}{ Purchase Intentions } & $10.025(2.653)$ \\
\hline & 0.000 & & 0.000 \\
\hline \multirow{2}{*}{ Perceived Value } & $21.436(2.653)$ & \multirow{2}{*}{ Word of Mouth } & $2.808(2.654)$ \\
\hline & 0.000 & & 0.040 \\
\hline
\end{tabular}

is 0.040 . The result shows that according to level of product information and level of product service, there is difference in perceived value, perceived risk, purchasing intention, and word of mouth.

Second, we use PLS structural equation model to analyze whether level of product information and level of product service affect perceived value, perceived risk, purchase intention and word of mouth.

Value of Construct extract four webpage construct value through Second Order Analysis For example, Perceived risk has extracted first webpage's risk value(adequate product information and adequate service information), second webpage's risk value(adequate product information and inadequate service information), third webpage's risk value(inadequate product information and adequate service information), fourth webpage's risk value(inadequate product information and inadequate service information)

The measurement model is first examined for

$<$ Table 5> Fit Indices for each of the hypothesized models

\begin{tabular}{|c|c|c|c|c|c|c|c|}
\hline Construct & Item & AVE & C. $\mathrm{R}$. & R Square & $\begin{array}{c}\text { Cronbach } \\
\text { a }\end{array}$ & $\begin{array}{c}\text { Communalit } \\
y\end{array}$ & $\begin{array}{c}\text { Redundan } \\
\text { cy }\end{array}$ \\
\hline $\mathrm{P}$ & 4 & 0.518 & 0.746 & & 0.755 & 0.518 & \\
\hline $\mathrm{S}$ & 4 & 0.571 & 0.701 & & 0.787 & 0.571 & \\
\hline $\mathrm{V}$ & 4 & 0.597 & 0.816 & 0.408 & 0.719 & 0.597 & 0.009 \\
\hline $\mathrm{R}$ & 4 & 0.649 & 0.828 & 0.282 & 0.840 & 0.649 & 0.013 \\
\hline I & 4 & 0.672 & 0.887 & 0.442 & 0.882 & 0.672 & 0.021 \\
\hline W & 3 & 0.571 & 0.799 & 0.333 & 0.783 & 0.571 & 0.001 \\
\hline \multicolumn{2}{|c|}{ Average } & 0.596 & 0.796 & 0.366 & 0.794 & 0.596 & 0.011 \\
\hline \multicolumn{2}{|c|}{$\begin{array}{c}\text { Fit indices of } \\
\text { Research Model }\end{array}$} & \multicolumn{6}{|c|}{0.467} \\
\hline
\end{tabular}


$<$ Table 6> Discriminant validity

\begin{tabular}{c|c|c|c|c|c}
\hline Construct & AVE & & Construct & AVE & R2 \\
\hline $\mathrm{P}$ & 0.518 & $\Leftrightarrow$ & $\mathrm{S}$ & 0.571 & 0.358 \\
\hline $\mathrm{P}$ & 0.518 & $\Leftrightarrow$ & $\mathrm{V}$ & 0.597 & 0.353 \\
\hline $\mathrm{P}$ & 0.518 & $\Leftrightarrow$ & $\mathrm{R}$ & 0.649 & 0.387 \\
\hline $\mathrm{P}$ & 0.518 & $\Leftrightarrow$ & $\mathrm{I}$ & 0.672 & 0.151 \\
\hline $\mathrm{P}$ & 0.518 & $\Leftrightarrow$ & $\mathrm{W}$ & 0.571 & 0.142 \\
\hline $\mathrm{S}$ & 0.571 & $\Leftrightarrow$ & $\mathrm{V}$ & 0.597 & 0.295 \\
\hline $\mathrm{S}$ & 0.571 & $\Leftrightarrow$ & $\mathrm{R}$ & 0.649 & 0.217 \\
\hline $\mathrm{S}$ & 0.571 & $\Leftrightarrow$ & $\mathrm{I}$ & 0.672 & 0.106 \\
\hline $\mathrm{S}$ & 0.571 & $\Leftrightarrow$ & $\mathrm{W}$ & 0.571 & 0.080 \\
\hline $\mathrm{V}$ & 0.597 & $\Leftrightarrow$ & $\mathrm{R}$ & 0.649 & 0.270 \\
\hline $\mathrm{V}$ & 0.597 & $\Leftrightarrow$ & $\mathrm{I}$ & 0.672 & 0.266 \\
\hline $\mathrm{V}$ & 0.597 & $\Leftrightarrow$ & $\mathrm{W}$ & 0.571 & 0.229 \\
\hline $\mathrm{R}$ & 0.649 & $\Leftrightarrow$ & $\mathrm{I}$ & 0.672 & 0.313 \\
\hline $\mathrm{R}$ & 0.649 & $\Leftrightarrow$ & $\mathrm{W}$ & 0.571 & 0.239 \\
\hline $\mathrm{I}$ & 0.672 & $\Leftrightarrow$ & $\mathrm{W}$ & 0.571 & 0.196 \\
\hline
\end{tabular}

validating and refining the research instruments, as well as assessing reliability. Then, the research model is tested.

Convergent validity, which indicates the extent to which the items of a scale theoretically related to each other are related in reality, is verified by examining the composite reliability (C.R.) and the average variance extracted (AVE). Acceptable values of C.R. and AVE should be greater than 0.7 and 0.5 respectively (Fornell \& Larcker, 1981). In this study, the items' factor loadings are all greater than 0.7. As shown in Table 5, all C.R. and AVE values satisfy the recommended threshold.

Discriminant validity measures whether a given construct is different from other constructs. It is assessed by one criterion: the AVE for each construct should be greater than the correlations square between the construct and other constructs (Fornell \& Larcker, 1981). It is clearly shown in Table 6 that all AVE values are greater than each rows, demonstrating discriminant validity.

The results of path analysis indicate that level of product information positively influences on perceived value $(\mathrm{H} 1=0.420, \mathrm{t}$-value $=5.900)$, therefore, $\mathrm{H} 1$ is adopted. This is similar to the study conducted by Koufaris \& Hampton(2004) which stated that the product information affects perceived value. The quantity of product information affects customers' perceived value of products directly. Therefore customers adjust perceived value according to level of product information. The more complete the product information is, the larger the perceived value is.

Level of product information negatively 
$<$ Table 7> Results of Path Analysis

\begin{tabular}{l|l|c|c|c}
\hline Hypotheses & \multicolumn{1}{|c|}{ Path } & $\begin{array}{c}\text { Path } \\
\text { Coefficient }\end{array}$ & t-value & Result \\
\hline H1 & Products Information ・ Value & 0.420 & 5.900 & Adopt \\
\hline H2 & Products Information ・ Risk & -0.492 & 5.788 & Adopt \\
\hline H3 & Service Quality ・ Value & 0.292 & 3.763 & Adopt \\
\hline H4 & Service Quality ・ Risk & -0.262 & 2.897 & Adopt \\
\hline H5 & Value ・ Risk & -0.213 & 2.841 & Adopt \\
\hline H6 & Value ・ Purchase Intention & 0.378 & 6.841 & Adopt \\
\hline H7 & Value ・ Word of Mouth & 0.339 & 3.215 & Adopt \\
\hline H8 & Risk • Purchase Intention & -0.441 & 8.362 & Adopt \\
\hline H9 & Risk ・ Word of Mouth & -0.267 & 2.162 & Adopt \\
\hline
\end{tabular}

influences on perceived risk $(\mathrm{H} 2=-0.492$, $\mathrm{t}$-value $=5.788)$, therefore, $\mathrm{H} 2$ is adopted. This is in accordance with the study conducted by Park et al.(2005) which stated that people exposed to Web sites with products in motion and larger product images will perceive less risk.

Service quality positively influences on perceived value $(\mathrm{H} 3=0.292, \mathrm{t}$-value $=3.763)$, therefore, $\mathrm{H} 3$ is adopted. The result accord with the study of Taylor \& Hunter(2002) which stated that service quality affects perceived value. Because the quality of service affects customers' perceived value directly, the quality of service is an important part of product value.

Service quality negatively influences on perceived risk $(\mathrm{H} 4=-0.262, \mathrm{t}$-value $=2.897)$, therefore $\mathrm{H} 4$ is adopted. The result accord with study of Blackwell et al.(2001) which stated service quality will perceive less risk.

Perceived value negatively influences on perceived risk $(\mathrm{H} 5=-0.213, \mathrm{t}$-value $=2.841)$, therefore, H5 is adopted. This is in accordance with the study conducted by Ernst \& Young(2001) which stated perceived value negatively affects perceived risk.

Perceived Value positively influences on purchase intention $(\mathrm{H} 6=0.378$, t-value $=$ 6.841), therefore, H6 is adopted. This is in accordance with the study conducted by Dumond(2000) who stated perceived value affects perceived intention. The higher customers' perceived value is, the larger the purchase intention is.

Perceived value positively influences on word of mouth $(\mathrm{H} 7=0.339$, $\mathrm{t}$-value $=3.215)$, therefore, H7 is adopted. This is in accordance with the study conducted by Lin et al. (2005), which stated that perceived value affects perceived word of mouth. The higher customers' perceived value is, the larger the word of mouth is. 
Perceived risk negatively influences on purchase intention $(\mathrm{H} 8=-0.441$, $\mathrm{t}$-value $=$ 8.362), therefore $\mathrm{H} 8$ is adopted. This is in accordance with the study conducted by Vijayasarathy \& Jones (2000), which stated that perceived risk negatively affects perceived intention.

Perceived risk negatively influences on word of mouth ( $\mathrm{H} 9=-0.267, \mathrm{t}$-value $=2.162)$, therefore H9 is adopted. This is in accordance with the study conducted by Yoh et al. (2003) which stated that perceived risk negatively affects perceived word of mouth.

\section{Conclusion}

\subsection{Research Finding}

The purpose of this paper is to find out the difference of consumer attitude based on level of product information and level of service quality. And we aim to find out the influence of product information and service quality on perceived value, perceived risk, purchase intention and word of mouth.

In our study, we designed four kinds of web pages which display different levels of product information and service quality. We distributed these four kinds of web pages together to each respondent and asked him to answer the questionnaire after looking through these four kinds of different web pages. Also, if we distribute the questionnaires in the same order, the learning effect has arisen. In order to remove the learning effect, we distribute the questionnaires in special order. The results of the study can be summarized as follows.

First, given web pages with different levels of product information and levels of service quality, respondents can answer differently. Based on our questionnaire, we can see that if there is adequate information about a product and service quality in the online shop, the customer will choose it more easily.

Second, there is difference in perceived value, perceived risk, purchasing intention, and word of mouth based on level of product information and level of product service.

Third, factors have a significant effect on both mutual relation and preceding relations. The results indicate that level of product information has a significant direct impact on perceived value and perceived risk. And, level of service quality has a significant direct impact on perceived value and perceived risk. Moreover, perceived value has a significant direct impact on perceived risk, purchase intention and word of mouth. Also, perceived risk has a significant direct impact on purchase intention and word of mouth.

\subsection{Implication}

The implications of our study are summarized as follows. First, most of previous studies were 
based on the technology acceptance model (TAM), however, insufficient studies have been done on product information and level of product service.

Second, we designed four kinds of web pages to survey our respondents how they perceive these web pages. And during our survey, we distributed the questionnaires in the order, the number of possibilities of which is a factorial of 4. With this method, we prove that our analytical results are only related to level of product information and level of service quality, while the results are not directly related to the order of distribution of questionnaire and respondents themselves. Moreover, we have also removed the learning effect of the individual situation where data are collected from respondents.

Third, we also reveal the relationship among factors, level of product information and level of product service quality. We can see that the variables which are related to level of product information and level of service quality influence both mutual relation and preceding relations. Therefore, during online shopping, the perceived value and perceived risk will be influenced by the level of product information and service quality.

\subsection{Limitation}

The limitation and further direction of this study is described as follows. First, because the samples are different and the perceived part is different, although we removed the learning effect from the same respondent, the number of samples is small.

Second, although all hypotheses are adopted, Multi-Group analysis could be used, instead. In henceforth study, second-Order analysis is used in this study to verify the hypotheses.

Third, we used a model slightly different from the traditional marketing model. Because we focused on finding difference between consumer attitude based on level of product information and service quality, we could not exactly measure the changing attitude after recognizing. Therefore, the changing of consumer attitude in a variety of situations can be measured in henceforth research .

Finally, in further research, studies can be performed including relationships between other factors which influence online shopping as well as value, risk, purchase intention, and word of mouth.

\section{〈Reference〉}

Banerjee, A. and D. Fudenberg, "Word-of-Mouth learning," Games and Economic Behavior, Vol. 46, 2004, pp. 1-22.

Blackwell, R. D., P. W. Miniard, and J. F. Engel, Consumer Behavior, Harcourt College Publishers, 2001.

Chrysanthos, D., "The Digitization of Word of Mouth: Promise and Challenges of 
Online Feedback Mechanisms,"

Management Science, Vol. 49, No. 10, 2003, pp. 1407-1424.

Cunningham, L. F., J. H. Gerlach, M. D. Harper, and C. E. Young, "Perceived Risk and the Consumer Buying Process: Internet Airline Reservations," Journal of Service Management, Vol. 16, No. 4, 2005, pp. 357-372.

Davern, M. J., D. Te'eni, and J. Y. Moon, "Content versus Structure in Information Environments: A Longitudinal Analysis of Website Preferences," Proceedings of the Twenty-First International Conference on Information Systems, 2000, pp. 564-570.

Dhruv, G., R. L. Gopalkrishnan, R. Krishnan, and A. Sharma, "The Internet and the Price-Value-Loyalty Chain," Journal of Business Research, Vol. 56, No. 5, 2003, pp. 391-398.

Dumond, E. J., "Value Management: An Underlying Framework," International Journal of Operations and Production Management, Vol. 20, No. 9, 2000, pp. 1062 - 1077.

Eggert, A. and W. Ulaga, "Customer Perceived Value: A Substitute for Satisfaction in Business Markets?" Journal of Business and Industrial Marketing, Vol. 17, No. 2, 2002, pp. 107-118.

Ernst and Young, Information Security Survey, Ernst \& Young, London, 2001.
Fornell, C. and D. F. Larcker, "Structural Equation Models with Unobservable Variables and Measurement," Journal of Marketing Research, Vol. 18, No. 8, 1981, pp. 39-50.

Francois, A., J. Fernando, and P. M. Jay, "Examining the Impact of Service Quality: A Meta-Analysis of Empirical Evidence," The Journal of Marketing Theory and Practice, Vol. 17, No. 2, 2009, pp. 95-110.

Grewal, D. and M. Levy, "Retailing Research: Past, Present, and Future," Journal of Retailing, Vol. 83, No. 4, 2007, pp. 447-464.

Harold, W. W. and A. W. Linda, "SiteQual : An integrated measure of website quality," The Journal of Enterprise Information Management, Vol. 17, No. 6, 2004, pp. 430-440.

Hartnett, M., Shopper Needs Must be Priority, Discount Store News, Vol. 5, 1998, pp. 21-22.

Janda, S., P. J. Trocchia, and K. P. Gwinner, "Customer Perceptions of Internet Retail Service Quality," International Journal of Service Industry Management, Vol. 13, No. 5, 2002, pp. 412-431.

Jillian, C. S. and G. N. Soutar, "Consumer Perceived Value: The Development of a Multiple Item Scale," Journal of Retailing, Vol. 77, No. 2, 2001, pp. 203-220. 
Julian, C. S., N. S. Geoffrey, and W. J. Lester, "The Role of Perceived Risk in the Quality-Value Relationship: A Study in a Retail Environment," Journal of Retailing, Vol. 75, No. 1, 1999, pp. 77-105.

Kim, J. and J. Lee, "Critical Design Factors for Successful E-Commerce Systems," Behaviour and Information Technology, Vol. 21, No. 3, 2002, pp. 185-189.

Kimery, K. and M. McCord, "Third-Party Assurances: Mapping the Road to Trust in E-retailing," The Journal of Information Technology Theory and Application, Vol. 4, No. 2, 2002, pp. 63-82.

Klein, L. R., "Evaluating the Potential of Interactive Media through a New Lens: Search Versus Experience Goods," Journal of Business Research, Vol. 41, 1998, pp. 195-203.

Koufaris, M. and S. W. Hampton, "The Development of Initial Trust in an Online Company by New Customers," Information and Management, Vol. 41, No. 3, 2004, pp. 377-397.

Lee, H. K.,"Developing Customer-Oriented Service Model in the Electronic Commerce : Focus on the Customer Value, Service Quality and Performance," Korea Association of Journal of Information Systems, Vol. 14, No. 1, 2005, pp. 125-147.
Leonard, L. B., S. Kathleen, and G. Dhruv, "Understanding Service Convenience," Journal of Marketing, Vol. 66, No. 7, 2002, pp. 1-17.

Liao, Z. and M. T, Cheung, "Internet based E-banking and Consumer Attitudes: An Empirical Study," Information and management, Vol. 39, No. 4, 2002, pp. 283-295.

Lightner, N. J, Strategies for designing Usable Interfaces for Internet Applications, Usability Evaluation and Interface Design, 2001, pp. 1387-1389.

Lin, C. H., P. J. Sher, and H. Y. Shin, "Past progress and Future directions in Conceptualizing customer perceived value," International Journal of Service Industry Management, Vol. 16, No. 4, 2005, pp. 318-336.

Miyazaki, A. D. and A. Fernandez, "Consumer Perceptions of Privacy and Security Risks for Online Shopping," Journal of Consumer Affairs, Vol. 35, No. 1, 2001, pp. 27-44.

Nancy, J. L, "User Preference for Product Information in Remote Purchase Environments," Journal of Electronic Commerce Research, Vol. 3, No. 3, 2002, pp. 174-186.

Oh, H.. "Price Fairness and Its Asymmetric Effects on Overall Price, Quality, and Value Judgements: The Case of a Upscale Hotel," Tourism Management, 
Vol. 24, 2003, pp. $241-249$.

Parasuraman, A., "Reflections on Gaining Competitive Advantage through Customer Value," Journal of the Academy of Marketing Science, Vol. 25, No. 2, 1997, pp. 154-161.

Park, J., "A Consumer Shopping Channel Extension Model: Attitude Shift toward the Online Store," Journal of Fashion Marketing and Management, Vol. 9, No. 1, 2005, pp. 106-121.

Park, J. H., J. L. Sharron, and S. Leslie, "On-Line Product Presentation: Effects on Mood, Perceived Risk, and Purchase Intention," Psychology and Marketing, Vol. 22, No. 9, 2005, pp. $695-719$.

Pavlou, P. A., "Consumer Acceptance of Electronic Commerce: Integrating Trust and Risk with the Technology Acceptance Model," International Journal of Electronic Commerce, Vol. 7 , No. 3, 2003, pp. 101-134.

Petrick, J. F., "First timers' and repeaters' Perceived Value," Journal of Travel Research, Vol. 43, No. 1, 2002, pp. 29-38.

Ratchford, B. T., X. Pan, and V. Shankar, "On the Efficiency of Internet Markets for Consumer Goods," Journal of Public Policy and Marketing, Vol. 22, No. 1, 2003, pp. 4-16.

Reichheld, F. F., Learning from Customer Defections, Harvard Business Review,
1996.

Robert, K., "The Sufficiency of Product and Variable Costs for Production-related Decisions when Economies of Scope are present," International Journal of Production Economics, Vol. 114, No. 2, 2008, pp. 682-696.

Sirdeshmukh, D., J. Singh, and B. Sabol, "Consumer Trust, Value, and Loyalty in Relational Exchanges," Journal of Marketing, Vol. 66, 2002, pp. 15-37.

Son, G. H., and H. G. Lee, "The Influence of Media, Consumer, and Product Characteristics on Perceived Risk and Purchasing Intention," Korea Association of Journal of Information Systems, Vol. 12, No. 1, 2003, pp. 117-144.

Taylor S. A. and G. L. Hunter, "The Impact of Loyalty with E-CRM Software and E-Services," International Journal of Service Industry Management, Vol. 13, No. 5, 2002, pp. 452-474.

Vijayasarathy, L. R. and J. M. Jones, "Intentions to Shop Using Internet Catalogues: Exploring the Effects of Product Types, Shopping Orientations, and Attitudes towards Computers," Electronic Markets, Vol. 10, No. 1, 2000, pp. 29-38.

Wang, Y. S., T. I. Tang, and J. E., Tang, "An Instrument for Measuring Customer Satisfaction Toward Web Sites That Market Digital Products and Services," 
Journal of Electronic Commerce, Vol. 2, No. 1, 2001, pp. 1-19.

Yoh, E., M. L. Damhorst, S. Sapp, and R. Lazniak, "Consumer Adoption of the Internet: The Case of Apparel Shopping," Psychology and Marketing, Vol. 20, No. 12, 2003, pp. 1095 - 1118.

Yoon, J. H., J. B. Chung, and Y. M. Kim,"A Study on the e-CRM, Customer Satisfaction, Repurchase Intention and Word of Mouth Intention in the Internet Shopping Mall," Korea Association of Journal of Information Systems, Vol. 17, No. 1, 2008, pp. 63-82.

Zeithaml, V. A., "Service Excellence in Electronic Channels," Managing Service Quality, Vol. 12, No. 3, 2002, pp. 135-139.

Zeithaml, V. A. and M. J. Bitner, Service Marketing: Integrating Customer Focus Across the Firm, London: McGraw-Hill, 2000.

\section{장활식 (Hwal-Sik Chang)}

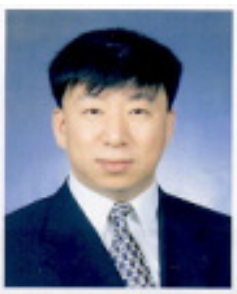

이다
현재 부산대학교 경영학부 교수로 재직중이며, 부산대학교 에서 학사, University of Oregon에서 석사, Texas Tech University에서 박사학위를 취 득하였다. 관심분야는 $\mathrm{ERP}$, $\mathrm{DSS}, \mathrm{IT}$ 성과 측정 및 평가 등

\section{조평총 (Ping-Cong Zhao)}

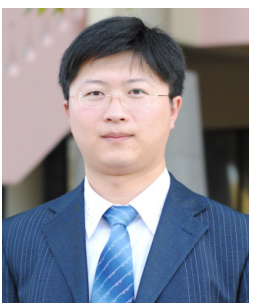

Economy and Information College, Jilin University에서 학사, 부산대학교 경영학과에서 석사학위를 취득하고, 동대학원 박사과정중에 있다. 관심분야는 $\mathrm{EC}, \mathrm{KM}, \mathrm{SCM}, \mathrm{ERP}$ 등이다

\section{박광오 (Kwang-Oh Park)}

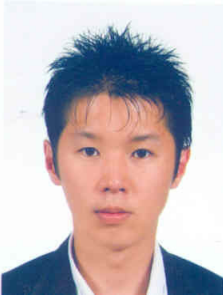

부산대학교 경영학과에서 석사학위, 동대학원에서 박사 학위를 취득하고, 현재 부산대 학교 강사로 재직중이다. 관심 분야는 SCM, ERP, EC, IT 성과 측정 및 평가 등이다. 
<국문초록>

\title{
상품정보제공수준과 서비스제공수준에 따른 소비자 태도 차이에 관한 연구
}

\author{
장활식* · 조평총** · 박광오***
}

전자상거래의 급속한 발전 속에서 기업들은 세계적 시장에서 경쟁력을 지니기 위해 전자상거래를 이 용하여 상품판매, 서비스 제공, 고객과 소통하고자 한다. 그러나, 기존의 연구들은 TAM 모형을 통한 상 호관계나 선행관계에만 초점을 맞추고 있기 때문에 좀 더 확장한 모형이 필요하다. 본 연구에서는 상품 정보와 서비스 제공수준은 소비자 행동에 영향을 미치는 중요한 요인이지만 연구가 충분치 못한 실정이 다.

따라서 본 연구의 목적은 첫째, 상품정보제공수준과 서비스제공수준에 따른 소비자 태도 차이를 조망 하고자 한다. 둘째, 기존에 연구가 미약하였던 상품정보제공수준 및 서비스제공수준과 기존에 인지된 가 치, 인지된 위험, 구매의도와 구전의도간의 상호인과관계를 조망하고자 한다.

본 연구의 결과는 다음과 같다. 첫째, 상품정보제공수준과 서비스제공수준에 따라 소비자 태도 차이 에는 차이가 있었다. 둘째, 상품정보제공수준과 서비스제공수준에 따라 소비자들이 인지된 가치, 인지 된 위험, 구매의도, 구전효과에는 차이가 있었다. 셋째, 변수들간에 상호인과관계와 선행관계가 존재하 였다. 상품정보제공수준과 서비스 제공수준은 인지된 가치와 인지된 위험에 각각 직접적인 영향을 미쳤 다. 뿐만 아니라, 인지된 가치는 인지된 위험, 구매의도, 구전효과에, 인지된 위험은 구매의도와 구전효 과에 직접적인 영향을 나타내었다.

Keywords : 상품정보제공수준, 서비스제공수준, PLS

* Professor, School of Business Administration, Pusan National University, Pusan, Korea

** Ph. D. Course, School of Business Administration, Pusan National University, Pusan, Korea

*** Ph. D., School of Business Administration, Pusan National University, Pusan, Korea

* 이 논문은 2010년 3월 30일 접수하여 1차 수정을 거쳐 2010년 8월 5일 게재 확정되었습니다. 